\title{
Gastrin response to meals of different composition in normal subjects
}

\author{
E. L. BLAIR, J. R. GREENWELL, E. R. GRUND, J. D. REED, AND \\ D. J. SANDERS
}

From the Department of Physiology, The University, Newcastle upon Tyne

SUMMARY The serum gastrin responses and the integrated gastrin responses to eating three meals of very different composition were studied in the same normal subjects on different days. Two meals, a milk meal of $500 \mathrm{ml}$, and a breakfast of eggs, toast, butter, marmalade, fruit juice and coffee, were eaten at breakfast time. The serum gastrin responses to these meals were compared and contrasted with the concentrations observed when the subjects fasted over the same time of day. A steak meal was eaten at lunch time. There were no significant differences between the mean serum gastrin concentrations to the three meals but each meal produced a significant increase in serum gastrin above fasting levels. When the prefeeding gastrin concentration was subtracted from the gastrin responses then the integrated responses to the steak meal were greater than those to either of the breakfast meals.

Considerable variability in response to any one meal was observed within the group of subjects, but those subjects who produced high serum gastrin concentrations to one meal did so to the others. Conversely, a low response to one meal was reflected in low responses to the other two meals. Fasting serum gastrin concentration was correlated with the age of the subject. Repeatability of the response to one meal was tested in two subjects who ate the same meal on four separate occasions showing their responses to be repeatable.

In the past decade the radioimmunoassay of gastrin has provided a new and sensitive tool which enables gastroenterologists to measure plasma gastrin concentrations in all manner of conditions, including the Zollinger-Ellison syndrome (Isenberg, Walsh, Passaro, Moore, and Grossman, 1972). The hypotheses involving vagal release of gastrin (Maung Pe Thein and Schofield, 1959) have been amply confirmed as has the inhibition of gastrin release by acidification of the antrum (Ganguli and Hunter, 1972).

In the quest to understand better the physiology of gastric secretion and to investigate the possible role of gastrin in the aetiology of peptic ulceration, different workers have used a variety of meals to stimulate and study gastrin secretion. The composition of the meals have ranged from two Oxo cubes (Byrnes, Young, Chisholm, and Lazarus, 1970), through a standard breakfast of boiled eggs, fruit juice, toast, marmalade and coffee to the more substantial steak meal and a sweet (Wyllie, Boulos,

Received for publication 9 July 1975.
Lewin, Stagg, and Clark, 1972).

The protein, fat, carbohydrate and calorific value of these meals varies greatly and yet there is no apparent relationship between these constituents and the resulting plasma gastrin. For example, the responses reported by Byrnes et al (1970) to two Oxo cubes was $4700 \mathrm{pg} / \mathrm{ml}$ whereas that to eggs, steak, cheese and milk (Reeder, Jackson, Ban, Davidson, and Thompson, 1970) was a mean $78 \mathrm{pg} / \mathrm{ml}$. Any comparison of these values is virtually prohibited by the existence of two major variables between different laboratories. First, different antisera were used in each laboratory and the characteristics of these are almost certainly different such that the 'gastrin' concentration of the same sample would differ, dependent upon the antisera used (Hansky, Soveny, and Korman, 1974).

Secondly, no comparison has been made of the responses of the same subjects to different meals in the same laboratory. There are considerable variations in fasting gastrin in samples from normal subjects in each laboratory (table IV for details) suggesting that there is a considerable spread of fasting 766 
gastrin in the normal population which may well be reflected in the stimulated responses, illustrating the danger of making comparisons between different small groups. Furthermore, no analysis has been made of the repeatability of the gastrin response to any one meal in the same subject and, therefore, there remains the possibility that the great variability in responses to different meals reflects the variability of each subject.

Without a strict characterization of these responses to various meals, coupled with strictly characterized assay systems, it is impossible to compare the values from different laboratories and therefore to obtain baseline normal data with which comparisons of suspect pathophysiological conditions can be made.

We have compared the plasma gastrin responses of a group of subjects to three meals of widely different composition. In two subjects the responses were studied to one meal repeated on a number of occasions.

\section{Methods}

Eleven male volunteer subjects free of dyspepsia (mean age 33.3 \pm 2.5 years) were studied on a number of occasions. Following an overnight fast an indwelling intravenous cannula was inserted into a forearm vein the next morning and two fasting samples were collected at 15-minute intervals. Subjects ate either the standard breakfast of two boiled eggs, coffee, two slices of toast, butter and marmalade and $150 \mathrm{ml}$ of orange juice, or drank the milk meal of 200 $\mathrm{ml}$ of milk concentrate (Carnation Foods Ltd) diluted to $500 \mathrm{ml}$ with water, or they continued to fast.

The third meal was eaten three and a half hours after a standard breakfast by subjects who had fasted overnight. This meal was a steak lunch of $200 \mathrm{~g}$ lentil soup, $200 \mathrm{~g}$ steak, $100 \mathrm{~g}$ creamed potatoes, $50 \mathrm{~g}$ peas and gravy, followed by dessert of caramel creme or fruit salad and coffee. Plasma samples were collected $15 \mathrm{~min}$ before and immediately before eating. Following the completion of each meal or during the prolonged fast blood 'samples were taken at $15,30,45,60,75,105,135,165$ and 195 minutes. Samples were collected into plain tubes, allowed to clot, and serum samples stored at $-20^{\circ} \mathrm{C}$ for subsequent assay of gastrin.

Serum gastrin concentration was determined by radioimmunoassay using purified, mono-iodinated SHGl as the label (Stadil and Rehfeld, 1972) and an antibody raised in rabbits against the hexadecapeptide 2-17 sequence conjugated covalently by car bodiimide to bovine serum albumin (McGuigan, 1968).

The binding energy expressed by the equilibrium constant was $4 \times 10^{11}$ litres $/ \mathrm{mol}$ and the sensitivity of the assay (detection limit) was $0.9 \mathrm{pg} /$ tube giving a normal working range of 10 to $1000 \mathrm{pg} / \mathrm{ml}$ of serum. The antiserum crossreacts equally on a molar basis with pure human big gastrinI in the ratio of $1: 86$ with pentagastrin (ICI 50123) and $1: 54$ with the approximately $15 \%$ pure $\mathrm{CCK} / \mathrm{PZ}$. Within-assay precision was calculated as the $95 \%$ confidence limits of at least 48 replicates of each dose of the standard curve of $2 \cdot 5,10,20$ and $50 \mathrm{pg}$ and was $0 \cdot 7,0 \cdot 7,1 \cdot 2$ and $1.7 \mathrm{pg}$ respectively. The between-assay reproducibility was assessed as the coefficient of variation of three serum samples assayed on a number of occasions over three months and these were between 10 and $15 \%$.

The serum gastrin values are calculated as $\mathrm{pg} \equiv$ $\mathrm{SHGI} / \mathrm{ml}$ and as the integrated serum gastrin responses, these being calculated as the area under the curve described by serum gastrin concentrations and the time studied. Both serum gastrin concentrations and integrated responses have also been calculated as the response above fasting value observed before the meal. The gastrin concentration after the meal is calculated by subtracting the fasting gastrin concentration immediately before the meal and the integrated gastrin responses after the meal by subtracting the integrated fasting gastrin calculated from the fasting concentration before the meal and the duration of the feeding response.

The results have been expressed as mean \pm 1 SEM (N) and analysed for significance of difference between means using Student's t test or Cochran's modification of this test. In appropriate cases the Wilcoxon rank test for paired data has been used. Regression analysis is by the method of least squares and calculation of slope (m), regression coefficient (r) and intercept (c).

\begin{tabular}{lllll}
\hline & Breakfast & Carnation Milk & Fasting & Steak \\
\hline First mean fasting \pm 1 SEM & $33 \cdot 9 \pm 13$ & $29 \cdot 1 \pm 10 \cdot 8$ & $28 \cdot 3 \pm 8 \cdot 6$ & $20 \cdot 0 \pm 7 \cdot 8$ \\
Second mean fasting \pm 1 SEM & $24 \cdot 1 \pm 10$ & $28 \cdot 9 \pm 10 \cdot 4$ & $28 \cdot 7 \pm 10 \cdot 0$ & $14.4 \pm 6 \cdot 2$ \\
Paired n & 10 & 10 & 11 & 10 \\
\hline
\end{tabular}

Table I Fasting plasma gastrin concentration taken before each meal or fasting ${ }^{1}$

${ }^{1}$ All values are expressed as $\mathrm{pg} \equiv \mathrm{SHG} 1 / \mathrm{ml}$ serum. There was no significant difference between any pair of observations $(P>0.4$ in each case). 


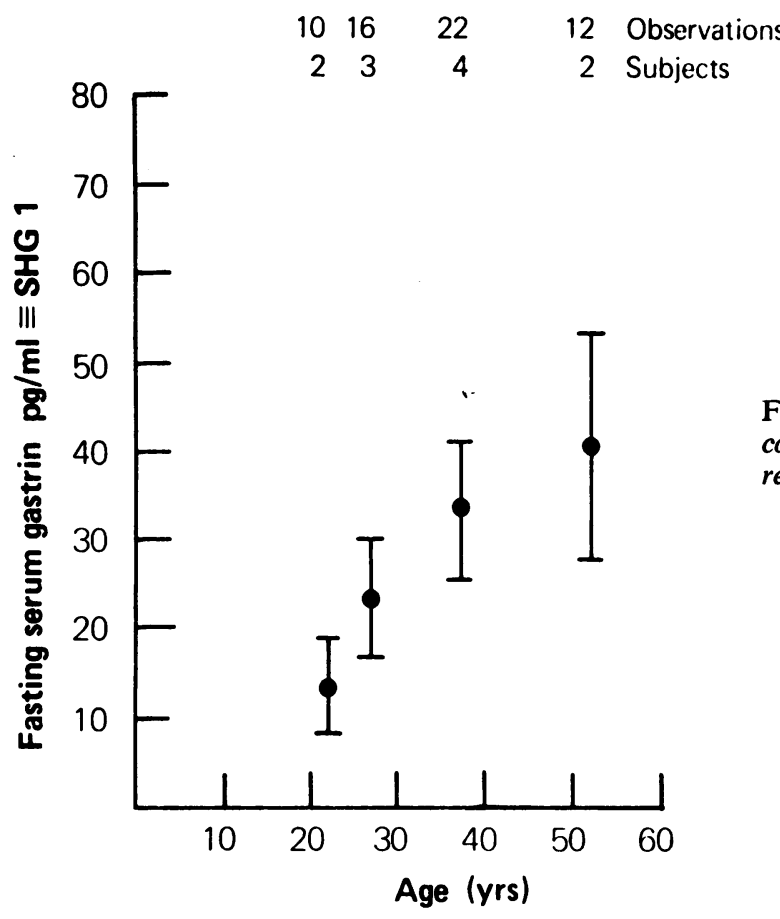

Fig 1 The relationship between fasting serum gastrin concentration and the age of the subjects. Points represent means and the bars 1 SEM.

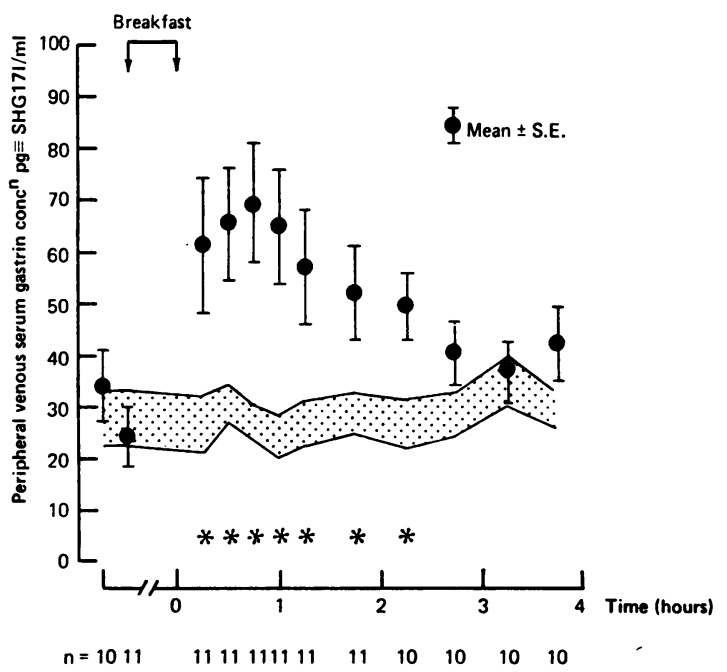

\section{Results}

FASTING VALUES

The fasting serum gastrin concentrations for the whole group (table I) show no significant differences between either the first or second estimations before each meal or between any of the mean values. The values obtained after an overnight fast show a direct relationship with the age of the subject (fig 1). During the prolonged fast there was no significant change in the mean serum gastrin concentration (fig 2).

\section{SERUM GASTRIN CONCENTRATIONS IN RESPONSE TO STANDARD MEALS}

\section{Breakfast}

The mean concentration of serum gastrin rose from a fasting $24.1 \pm 10 \mathrm{pg} / \mathrm{ml}$ to a peak of $69.4 \pm 11.4$ $\mathrm{pg} / \mathrm{ml}$ (11) 45 minutes after finishing the meal and

Fig 2 The relationship between the time following the end of the standard breakfast and the mean serum gastrin concentrations $(0)$ in 11 normal subjects. Bars represent \pm 1 SEM. The stippled area represents the mean \pm 1 SEM of the serum gastrin concentration in the same subjects observed during a prolonged fast over the same time course.

* represents significance of difference between the fasting means and the postmeal means at least at the $5 \%$ level. remained significantly elevated for two and a quarter hours (fig 2).

\section{The milk meal}

The mean serum gastrin concentration rose from a fasting mean of $28.9 \pm 10.4 \mathrm{pg} / \mathrm{ml}$ to a peak $65.8 \pm$ $13.4 \mathrm{pg} / \mathrm{ml}$ (10) one hour after completing the meal and remained significantly elevated for two and a quarter hours (fig 3). 


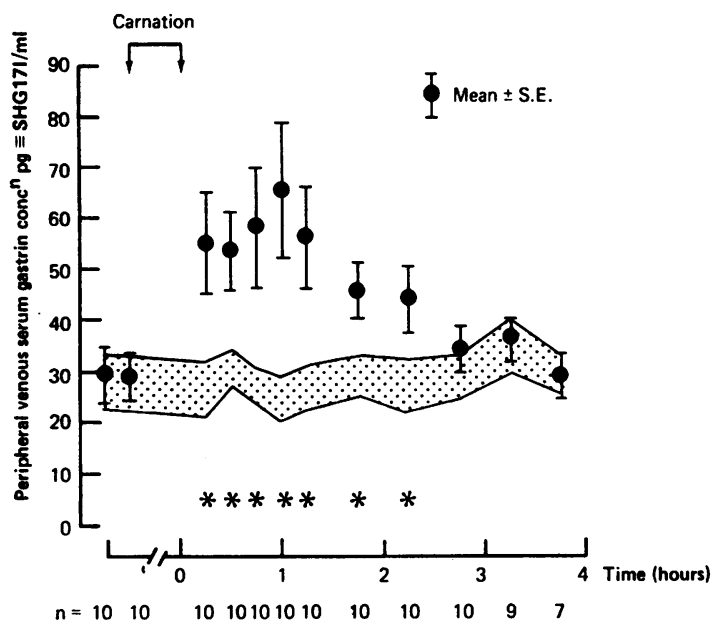

Fig 3 The relationship between the time following the end of drinking the milk meal and the mean serum gastrin concentrations (O) in 10 normal subjects; bars represent \pm 1 SEM. The stippled area represents the mean \pm 1 SEM of the prolonged fasting mean serum gastrin concentrations.

* represents significance of difference between means at $5 \%$ level.

The steak meal

The mean serum gastrin rose to a peak value of $84.2 \pm 32 \mathrm{pg} / \mathrm{ml}$ (10) $105 \mathrm{~min}$ after finishing the steak meal but this cannot be analysed for significance above fasting since no fasting study was made at this time of day (fig 4).

A comparison of the responses at equal intervals after finishing eating showed no significant differences between the means in response to any meal. There was no significant difference between the mean times taken for the same eight individuals to reach peak response to breakfast $(0.59 \pm 0.18 \mathrm{hr}$ or milk $0.88 \pm 0.8 \mathrm{hr}, \mathrm{P}>0.2$ ) but these times were

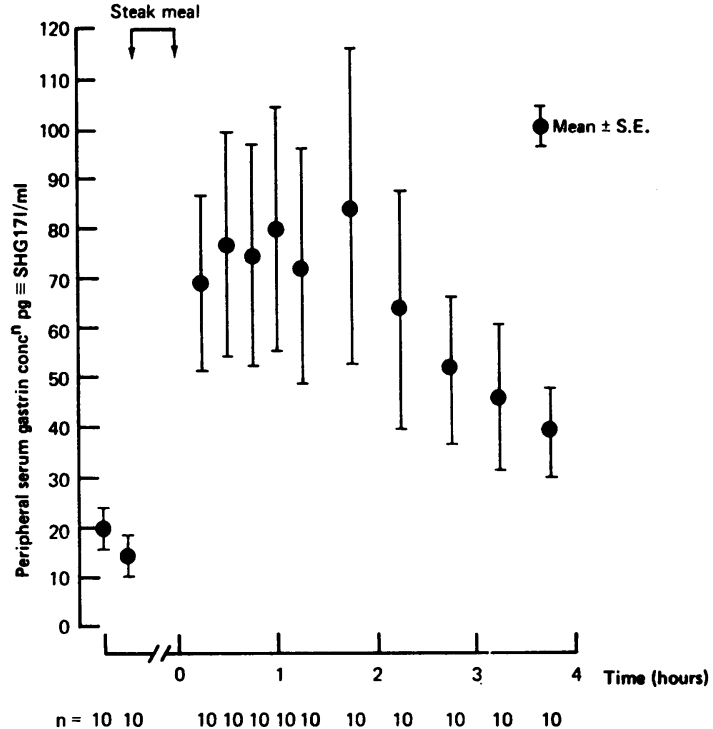

Fig 4 The relationship between the time after the end of the steak meal and the mean serum gastrin concentrations in 10 normal subjects; bars represent \pm 1 SEM.

significantly less than the mean time taken to reach peak following steak $(1.59 \pm 0.32 \mathrm{hr}, \mathrm{P}<0.01$ in each case).

\section{INTEGRATED GASTRIN RESPONSES IN}

RESPONSE TO STANDARD MEALS

The total integrated gastrin responses to the three meals showed no significant differences between the means ( $P>0.05$ in each case, table II). The responses calculated by subtracting the fasting values from the total revealed significant differences between the responses to the milk meal and the steak

\begin{tabular}{|c|c|c|c|c|c|c|}
\hline \multirow[t]{2}{*}{ Meal } & \multicolumn{3}{|c|}{ Gastrin Concentration $(\mathrm{pg} / \mathrm{ml})$} & \multicolumn{3}{|c|}{ Integrated Gastrin (ng) } \\
\hline & Fasting & Peak & $\begin{array}{l}\text { Peak minus } \\
\text { Fasting }\end{array}$ & Fasting & Total & $\begin{array}{l}\text { Total minus } \\
\text { Fasting }\end{array}$ \\
\hline Breakfast & $\begin{array}{r}31 \cdot 4 \pm 6.2 \\
P=\end{array}$ & .005 & $58 \cdot 0 \pm 12 \cdot 3$ & $\begin{array}{r}7 \cdot 96 \pm \underset{P=}{1 \cdot 31} \\
P=\end{array}$ & 01 & $5.02 \pm 1.83$ \\
\hline Milk & $\begin{array}{r}31 \cdot 3 \pm 5 \cdot 5 \\
P=\end{array}$ & .005 & $42 \cdot 9 \pm 11 \cdot 3$ & $\begin{array}{r}7 \cdot 02 \pm 1 \cdot 38 \\
P=\end{array}$ & $10.23 \pm 1.39$ & $4.05 \pm 1.37$ \\
\hline Steak & $\begin{array}{r}15 \cdot 1 \pm 4 \cdot 8 \\
P=\end{array}$ & 005 & $102 \cdot 5 \pm 32 \cdot 2$ & $\begin{array}{c}4 \cdot 18 \pm 1.06 \\
P=<\end{array}$ & 05 & $12.44 \pm 4.66$ \\
\hline Breakfast and steak & $<0.025$ & NS & $<0.01$ & $<0.05$ & NS & $<0.01$ \\
\hline Breakfast and milk & NS & NS & NS & NS & NS & NS \\
\hline Milk and steak & $\begin{array}{l}<0.025 \\
\text { Significance }\end{array}$ & $\begin{array}{l}\text { NS } \\
\text { ifferences betwee }\end{array}$ & $\begin{array}{l}<0.025 \\
\text { means }\end{array}$ & NS & NS & $<0.025$ \\
\hline
\end{tabular}

Table II Comparison of the serum gastrin responses to three standard meals in the same eight normal subjects 


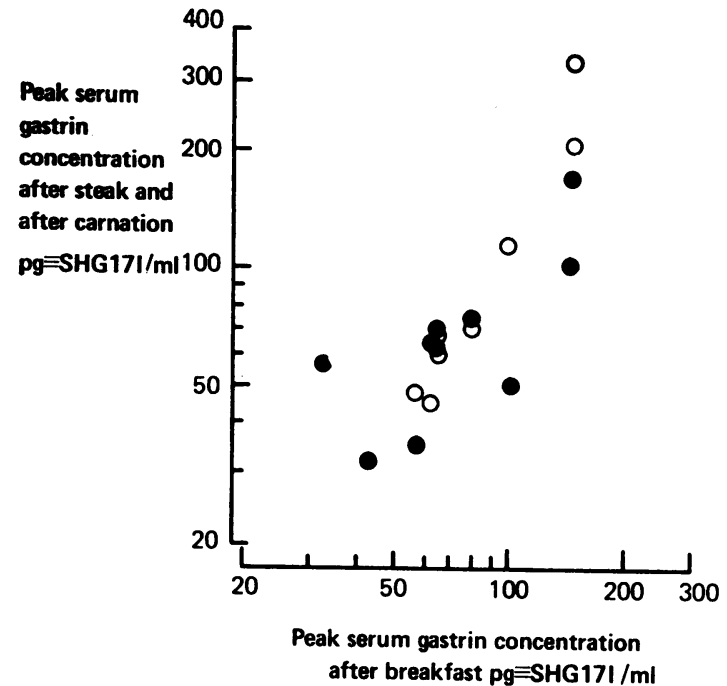

Peak after steak $v$ Peak after breakfast

$$
0
$$

$\mathrm{m}=1.8596$

corr. coef. $=0.9661$

$p=<0.01$

Peak after carnation $v$ Peak after breakfast $\mathrm{m}=0.9666$

corr. coef. $=0.7638$

$\mathrm{p}=<0.025$

Fig 5 Relationship between the peak serum gastrin concentrations following breakfast and the steak meal $(O)$ and between the breakfast and the milk meal (O) in normal subjects.

meal and between breakfast and the steak meal in eight subjects who ate each meal (table II).

There are considerable variations in the mean peak responses to each meal but any one subject responds similarly; eg, a subject who produces a large peak response to one meal produces a large response to the other meals (fig 5). This relationship is equally clear for $\log$ integrated gastrin responses to breakfast and log integrated gastrin responses to either milk $(r=0.8393, \mathrm{P}<0.01$, df6) or steak $(r=$ 0.7909, $P<0.02$, df6).

Neither the peak nor the integrated gastrin responses to any meal were correlated with the age of the subject ( $P>0.2$ in each case).

The reproducibility of the serum gastrin concentration following the breakfast meal was tested in two subjects, one of whom (ELB) showed a small response and the other (JDR) a large response when tested in the original series. Both subjects ate the standard meal on four occasions during a period of

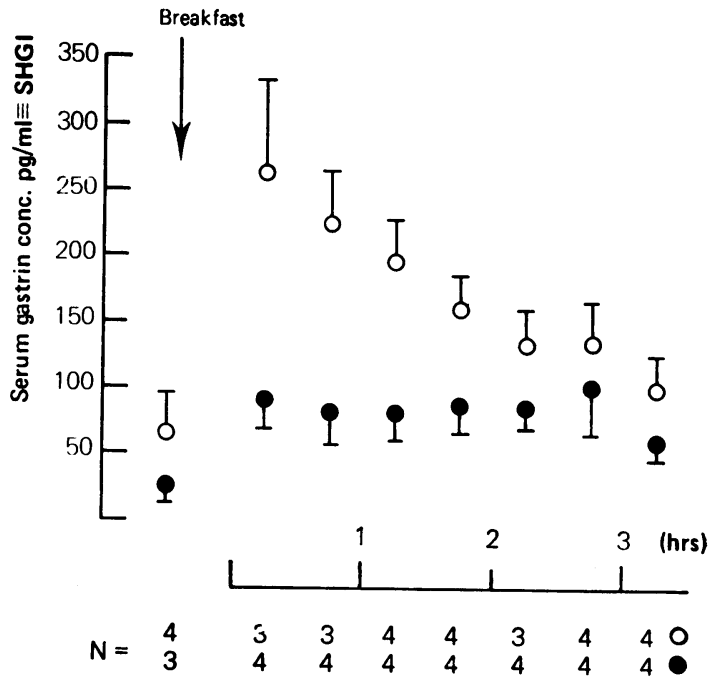

Fig 6 Comparison of the mean serum gastrin concentrations following eating the standard breakfast on a number of occasions in two subjects. Bars represent \pm 1 SEM.

either four (ELB) or nine months (JDR). Each subject's responses showed variability but this was not sufficient to obscure the serum gastrin pattern characteristic of each person (fig 6).

\section{Discussion}

The mean fasting serum gastrin concentrations determined on at least three occasions in each subject following overnight fasting (table I) are similar to the majority of the recently published values (table III). Where differences exist these may be

\begin{tabular}{llllc}
\hline Meal & Protein $(g)$ & Fat $(g)$ & Carbohydrate $(g)$ & Calories \\
\hline Breakfast & 18.0 & 31.0 & 65.0 & 610 \\
Milk & 17.0 & 18.3 & 26.7 & 366 \\
Steak & 75.6 & 65.6 & 86.4 & 1300 \\
\hline
\end{tabular}

Table III Dietary content of the three standard meals

attributable to the antibodies and labels used in the various laboratories but could be in part caused by the selection of subjects from a very heterogeneous population. The need to standardize the time of day and the preceding fasting conditions is illustrated by the observation that the serum gastrin concentrations observed in eight subjects three and a half hours after eating a standard breakfast, immediately before eating lunch $(15.1 \pm 4.8 \mathrm{pg} / \mathrm{ml})$ are significantly lower than those observed after an overnight 


\begin{tabular}{|c|c|c|c|}
\hline Authors & $\begin{array}{l}\text { Mean Gastrin } \\
\text { Concentration } \\
(p g / m l)\end{array}$ & $S E M$ & $\begin{array}{l}\text { No. of } \\
\text { Subjects }\end{array}$ \\
\hline $\begin{array}{l}\text { Hansky, Soveny, and Korman } \\
\text { (1973) }\end{array}$ & 36 & 1.7 & 264 \\
\hline $\begin{array}{l}\text { Muller, Fritsch, Rick, and } \\
\text { Hausamen (1973) }\end{array}$ & 82 & $\begin{array}{l}+7 \cdot 1 \\
-3.6\end{array}$ & 33 \\
\hline $\begin{array}{l}\text { McGuigan and Trudeau (1971) } \\
\text { Stadil and Rehfeld (1973) } \\
\text { Gedde-Dahl (1974) } \\
\text { Berson, Walsh, and Yalow (1973) } \\
\text { Ganguli and Hunter (1972) }\end{array}$ & $\begin{array}{l}85 \\
52 \\
65 \cdot 9 \\
30 \\
105\end{array}$ & $\begin{array}{l}9 \cdot 8 \\
4 \cdot 6 \\
2 \cdot 9 \\
5 \cdot 0 \\
7 \cdot 0\end{array}$ & $\begin{array}{r}35 \\
120 \\
205 \\
71 \\
113\end{array}$ \\
\hline $\begin{array}{l}\text { Bunchman, Reeder, and } \\
\text { Thompson (1971) } \\
\text { Maxwell, Moore, Dixon, and }\end{array}$ & 123 & $10 \cdot 0$ & 15 \\
\hline $\begin{array}{l}\text { Steven (1971) } \\
\text { Schrumpf and Sand (1972) }\end{array}$ & $\begin{array}{l}35 \\
62\end{array}$ & $\begin{array}{l}2 \cdot 1 \\
7 \cdot 0\end{array}$ & $\begin{array}{l}14 \\
21\end{array}$ \\
\hline
\end{tabular}

Table IV Examples of the published mean fasting gastrin concentrations in normal subjects

fast in the same eight subjects $(31.4 \pm 6.2 \mathrm{pg} / \mathrm{ml}$, $\mathbf{P}<0.005$ in each case, table II).

Like other workers (table III), we have observed considerable variation in the fasting serum gastrin concentration between individuals, although in part this might be accounted for by the different ages of the subjects (fig 1) (Trudeau and McGuigan, 1971).

It is possible to compare the responses to the standard breakfast and the milk meal since both were carried out in the same subjects at the same time of day and following the same overnight fasting conditions. Furthermore, both responses can be compared with the prolonged fasting values obtained over the same time period. The responses to both meals rose significantly to similar levels and remained above fasting values for two and a quarter hours. There were no significant differences between the mean serum gastrin concentrations at corresponding times after each meal (figs 2 and 3 ).

The steak meal was eaten at $1.30 \mathrm{pm}$ and the responses are, therefore, not strictly comparable with those to the other meals. Furthermore, the steak meal was eaten three and a half hours after eating a standard breakfast and fasting values were not observed over the duration of this steak meal response. Following the steak meal the mean serum concentrations of gastrin were not significantly different from those measured at the same times after the other two meals.

The peak responses to the three meals are shown in table II and compared with published values in table V. It is surprising, in spite of the considerable variation in composition and calorific values of the three meals (table III), that the responses are so similar. This similarity is evident in the reported responses to meals of even more varied composition (table V). We do not as yet know whether the acid secretory responses to meals of such varied composition differ in either magnitude or duration. If a more substantial meal does produce greater gastric acid secretion this cannot, from our evidence, be accounted for by differences in the gastrin concentration or the total integrated gastrin responses (table II).

It may be, however, that the different gastrin molecular species are released in different proportions in response to the various components of the meals. The major forms of gastrin reported to be released in response to feeding in man are the little and big gastrins. Little gastrin is biologically more active on a molar basis than both big gastrin and mini gastrin when tested in the dog (Debas, Walsh, and Grossman, 1974). Our antibody reacts equally

\begin{tabular}{|c|c|c|c|c|}
\hline Type of Meal & Authors & $\begin{array}{l}\text { Peak Mean } \\
\text { Gastrin } \\
\text { Concentration } \\
(p g / m l)\end{array}$ & $\begin{array}{l}\text { No. of } \\
\text { Subjects }\end{array}$ & Constitution of Meals \\
\hline Breakfast & $\begin{array}{l}\text { Berson, Walsh, and Yalow (1973) } \\
\text { Stern and Walsh (1973) } \\
\text { Korman, Soveny, and Hansky (1971) } \\
\text { Korman, Soveny, and Hansky (1971) }\end{array}$ & $\begin{array}{r}66 \\
138 \\
52 \\
57\end{array}$ & $\begin{array}{l}7 \\
8 \\
8\end{array}$ & $\begin{array}{l}\text { Standard breakfast } \\
\text { Standard breakfast } \\
\text { Scrambled egg, butter, pears and cream } \\
\text { (Protein } 27 \cdot 5 \mathrm{~g} \text {, fat } 61 \mathrm{~g}, \mathrm{CHO} 11.2 \mathrm{~g} \text { ) } \\
\text { Sugar, milk, toast } \\
\text { (Protein } 18 \mathrm{~g} \text {, fat } 9.5 \mathrm{~g}, \mathrm{CHO} 103 \mathrm{~g} \text { ) }\end{array}$ \\
\hline Liquid & $\begin{array}{l}\text { Becker, Reeder, and Thompson (1973) } \\
\text { Reeder, Jackson, Ban, Davidson, and } \\
\text { Thompson (1970) }\end{array}$ & $\begin{array}{l}122 \\
148\end{array}$ & $\begin{array}{r}10 \\
5\end{array}$ & $\begin{array}{l}\text { Liquid meal } \\
\text { (Protein } 63 \mathrm{~g} \text {, fat } 40 \mathrm{~g}, \text { CHO } 159 \mathrm{~g} \text { ) } \\
\text { Liquid meal } \\
\text { (Protein } 63 \mathrm{~g} \text {, fat } 40 \mathrm{~g}, \text { CHO } 159 \mathrm{~g} \text { ) }\end{array}$ \\
\hline Lunch & $\begin{array}{l}\text { McGuigan and Trudeau (1970) } \\
\text { Reeder, Jackson, Ban, Davidson, and } \\
\text { Thompson (1970) } \\
\text { Maxwell, Moore, Dixon, and Stevens (1971) } \\
\text { McGuigan and Trudeau (1973) } \\
\text { Ganguli and Hunter (1972) }\end{array}$ & $\begin{array}{l}100-345 \\
148 \\
70-175 \\
108 \\
180-220\end{array}$ & $\begin{array}{r}3 \\
10 \\
14 \\
10 \\
4\end{array}$ & $\begin{array}{l}240 \mathrm{~g} \text { steak } \\
2 \text { Slices toast } \\
\text { Steak, eggs, cheese and milk } \\
\text { (Protein } 60 \mathrm{~g} \text {, fat } 51 \mathrm{~g}, \text { CHO } 11 \mathrm{~g} \text { ) } \\
\text { (Protein } 60 \mathrm{~g} \text {, fat } 40 \mathrm{~g} \text {, CHO } 160 \mathrm{~g} \text { ) } \\
180 \mathrm{~g} \text { lean roast beef and water } \\
\text { Grilled steak }\end{array}$ \\
\hline
\end{tabular}

Table V Comparison of the published mean peak serum gastrin concentrations in response to meals of various compositions 
on a molar basis with big and little gastrin and is sensitive to mini gastrin (Blair, Grund, Lund, Reed, and Sanders, 1975). It is, therefore, possible that the similar total gastrin concentrations and total integrated responses to the three meals disguise different biological activities.

When the responses to the three meals are analysed by subtraction of the immediate preceding fasting value or the integrated fasting value, then the peak and the integrated responses to the steak meal are significantly greater than those to breakfast and to the milk meal, whereas the responses to milk and breakfast are not significantly different from one another (table II).

If the acid secretory response to the meat meal is greater than to the other meals, and this is due only to gastrin stimulation, then the parietal cell must be sensitive to changes in serum gastrin concentration rather than to the absolute concentration. It is, however, probable that a number of factors modify the response to gastrin, eg, vagal synergism may be greater during the meat meal. Should the acid response to the steak meal be no greater, then the demonstrated greater change in gastrin response (table II) must be meaningless and possibly artefactual.

The differences between responses-basal values to the three meals owe much to the fact that the fasting responses, subtracted from the peak and total integrated responses, are significantly lower before the steak meal than to the other two meals. Whether these differences are real or artefactual can only be resolved by carrying out fasting studies over the lunch period, preceded both by an overnight fast and by a meal at breakfast. The previously published evidence of plasma gastrin concentrations studied over the 24-hour period does not suggest that there are low concentrations immediately before lunch (Moore and Wolfe, 1973; Ganguli and Forrester, 1972) as compared with early morning.

There was a significant correlation between the gastrin responses to different meals in each subject (fig 5), confirming the fact that each subject responded consistently, ie, subjects who produced low responses to any one meal did so to the other meals and vice versa. The reproducibility of the gastrin response was tested in two subjects (fig 6). Although there was variation from test to test this was not such that it obscured the fact that one subject had a consistently low gastrin profile and the other a consistently high profile.

In conclusion it appears that the total gastrin concentrations and total integrated responses following each of the three meals are very similar. This similarity of response, in spite of the marked differences in the composition and size of the meals, may well indicate the existence of normal effective feedback mechanisms controlling the gastrin response.

Some pathophysiological conditions of the gastrointestinal tract may result from a failure of these feedback mechanisms to control the plasma gastrin concentrations. In such circumstances investigation of the gastrin responses to these three meals may prove to discriminate between these states and normals.

We are grateful to Mrs E. Nicholson for skilled technical assistance. E.R.G. was in receipt of a Luccock scholarship for training in research methods. CCK-PZ was a gift from Professor V. Mutt and big gastrin from Professor R. A. Gregory. This work was supported in part by a grant from the North of England Cancer Research Campaign for which we are very grateful.

References

Becker, H. D., Reeder, D.D., and Thompson, J. C. (1973). The effect of truncal vagotomy with pyloroplasty or with antrectomy on food stimulated gastrin values in patients with duodenal ulcer. Surgery, 74, 580-586.

Berson, S. A., Walsh, J. H., and Yalow, R. S. (1973). Radioimmunoassay of gastrin in human plasma and regulation of gastrin secretion. In Nobel Symposium 16. Frontiers in Gastrointestinal Hormone Research, edited by S. Anderson, pp. 57-66. Almqvist and Wiksell, Stockholm.

Blair, E. L., Grund, E. R., Lund, P. K., Reed, J. D., and Sanders, D. J. (1975). Immunoreactive gastrin variants in cat serum. $J$. Physiol. (Lond.), 247, 33P-34P.

Bunchman, H. H., Reeder, D. D., and Thompson, J. C. (1971). Effect of secretin on the serum gastrin response to a meal in man and in dog. Surg. Forum, 22, 303-304.

Byrnes, D. J., Young, J. D., Chisholm, D. J., and Lazarus, L. (1970). Serum gastrin in patients with peptic ulceration. Brit. med. J., 2, 626-629.

Debas, H. T., Walsh, J. H., and Grossman, M. I. (1974). Pure human minigastrin: secretory potency and disappearance rate. Gut, $15,686-689$.

Ganguli, P. C., and Forrester, J. M. (1972). Circadian rhythm in plasma levels of gastrin. Nature [New Biol.], 236, 127-128.

Ganguli, P. C., and Hunter, W. M. (1972). Radioimmunoassay of gastrin in human plasma. J. Physiol. (Lond.), 220, 499-510.

Gedde-Dahl, D. (1974). Radioimmunoassay of gastrin: fasting serum levels in humans with normal and high gastric acid secretion. Scand. J. Gastroent., 9, 41-47.

Hansky, J., Soveny, C., and Korman, M. G. (1973). Value of serum gastrin in the diagnosis of the Zollinger-Ellison syndrome. Aust. N.Z. Med., 3, 349-354.

Hansky, J., Soveny, C., and Korman, M. G. (1974). Studies with two gastrin antisera of different specificity for gastrins I and II. Digestion, 10, 97-107.

Isenberg, J. L., Walsh, J. H., Passaro, E. Jr., Moore, E. W., and Grossman, M. I. (1972). Unusual effect of secretin on serum gastrin, serum calcium and gastric acid secretion in a patient with suspected Zollinger-Ellison syndrome. Gastroenterology, 62, 626-631.

Korman, M. G., Soveny, C., and Hansky, J. (1971). Effect of food on serum gastrin evaluated by radioimmunoassay.Gut 12,619-624.

Maung Pe Thein, and Schofield, B. (1959). Release of gastrin from the pyloric antrum following vagal stimulation by sham feeding in dogs. J. Physiol. (Lond.), 148, 291-305.

Maxwell, J. G., Moore, J. G., Dixon, J., and Stevens, L. E. (1971). Gastrin levels in anephric patients. Surg. Forum, 22, 305-306.

McGuigan, J. E. (1968). Immunochemical studies with synthetic human gastrin. Gastroenterology, 54, 1005-1011.

McGuigan, J. E., and Trudeau, W. L. (1970). Serum gastrin concentrations in pernicious anemia. New Engl. J. Med., 282, 358-361.

McGuigan, J. E., and Trudeau, W. L. (1973). Differences in rates of 
gastrin release in normal persons and patients with duodenalulcer disease. New Engl. J. Med., 288, 64-66.

Moore, J: G., and Wolfe, M. (1973). The relation of plasma gastrin to the circadian rhythm of gastric acid secretion in man. Digestion, 9, 97-105.

Müller, J., Fritsch, W. P., Rick, W., and Hausamen, T. U. (1973) Die radioimmunologische Serumgastrinbestimmung. Med. Welt., 24, 1017-1018.

Reeder, D. D., Jackson, B. M., Ban, J. L., Davidson, W. D., and Thompson, J. C. (1970). Effect of food on serum gastrin concentrations in duodenal ulcer and control patients. Surg. Forum, 21, 290-291.

Schrumpf, E., and Sand, T. (1972). Radioimmunoassay of gastrin with activated charcoal. Scand. J. Gastroent., 7, 683-687.

Stern, D. H., and Walsh, J. H. (1973). Gastrin release in post operative ulcer patients: evidence for the release of duodenal gastrin.
Gastroenterology, 64, 363-369.

Stadil, F., and Rehfeld, J. F. (1972). Preparation of ${ }^{125}$ I-labelled synthetic human gastrin for radioimmunoassay. Scand. J. clin. Lab. Invest., 30, 361-368.

Stadil, F., and Rehfeld, J. F. (1973). Determination of gastrin in serum. An evaluation of the reliability of a radioimmunoanalysis Scand. J. Gastroent., 8, 101-112.

Trudeau, W. L., and McGuigan, J. E. (1971). Relations between serum gastrin levels and rates of gastric hydrochloric acid secretion New Engl. J. Med., 284, 408-412.

Wyllie, J. H., Boulos, P. B., Lewin, M. R., Stagg, B. H., and Clark, C. G. (1972). Plasma gastrin and acid secretion in man following stimulation by food, meat extract and insulin. Gut, 13, 887893.

Yalow, R., and Berson, S. A. (1970). Radioimmunoassay of gastrin. Gastroenterology, 58, 1-14. 